\title{
ONDE ESTÁ A ANTROPOLOGIA?
}

Mariza G. S. Peirano

Despite their pretense, the declaredly egalitarian, yet to be routinized, crosscultural dialogues are never in fact between equals, for the absence of a fully governing convention, of a mutually acceptable third, fosters hierarchy a (silent) assertion of authority over, an "understanding" of, the position of the interlocutor. (Or its opposite.) There is little to mediate - to attenuate the challenge each participant, coming, as it were, from somewhere else, poses to the other. (Vincent Crapanzano 1991)

An alliance of multiple interests and perspectives is often a stronger political and social force than attempts to enforce a unitary movement. (M ichael M.J. Fischer 1994)

\section{Clássicos, história teórica \& antropologia em contexto}

Nas comunidades transnacionais que são as ciências sociais é imprescindível uma ideologia comum que mantenha os ideais de universalidade e cimente as relações sociais entre cientistas de várias origens. É nesse contexto sociológico que estão situados os clássicos. A leitura e o conhecimento das obras assim consideradas formam os iniciados na tradição que, na antropologia, por exemplo, são aqueles praticantes que dominam o corpus etnográfico de alguns autores-chave que trouxeram o exótico à consciência do Ocidente e o utilizaram tanto para a tarefa mais óbvia e banal de servir como seu espelho existencial, quanto para a responsabilidade mais plena de refinar um instrumental teórico com pretensões universais. Os clássicos de uma disciplina são, portanto, criações sociologicamente necessárias e teoricamente indispensáveis, através dos quais os praticantes se identificam e se (re)produzem nos diversos contextos acadêmicos; eles tornam possível a existência de uma comunidade de cientistas sociais, daí derivando sua relevância singular e contínua. 
Reconhecer a centralidade dos clássicos, no entanto, não implica transformar as ciências sociais no relato delas, nem fazer da antropologia uma história da antropologia. Ao contrário, significa diferenciar propostas, internas e externas, entre os praticantes e os estudiosos de uma disciplina. Por mais que a historiografia da antropologia origine cada vez mais dados a considerar, as diversas histórias teóricas, resultado de reconstruções da teoria que permite iluminar dados etnográficos novos, são fenômenos internos à prática disciplinar ${ }^{1}$. É a aceitação, consciente ou não, de uma determinada história teórica que situa determinadas obras e/ou autores como clássicos de uma vertente e estabelece uma linhagem não só de etnógrafos, mas de perguntas e de problemas, de questionamentos teóricos enfim, que as novas gerações herdam, procuram responder e legam modificados a seus descendentes. Tal reconhecimento não faz dos clássicos autores eternos e desvinculados do contexto no qual têm origem e/ou são apropriados. Mas tem como resultado observar que, apesar das variações existentes, eles são essenciais para a continuidade de um conhecimento que, em determinadas circunstâncias, se tornou disciplinar: a questão de se saber quem são, onde são gerados, ou como se formam, embora extremamente importante, é secundária diante da sua existência indispensável2.

Tendo como pano de fundo essas propostas gerais (e reconhecido seu papel empírico tanto quanto normativo), este exercício tem por objetivo examinar questões relativas às diversas manifestações da antropologia em contextos contemporâneos. No momento em que se difunde a idéia do fim das disciplinas - temida por uns, celebrada por outros -, procuro examinar o resultado dos processos de aculturação que se desenvolvem no âmbito do mundo acadêmico, e que informam continuidades e questionamentos ${ }^{3}$. Estou interessada na possibilidade de termos universalismos no plural, preocupada com a base que sustenta a antropologia vis-à-vis a fragmentação de saberes, e curiosa a respeito do fato de, mesmo no contexto pós-moderno, clássicos continuarem indispensáveis. Neste ensaio, abordo essas questões abrangentes por intermédio de dois acessos etnográficos: em primeiro lugar, uma visita a livrarias norte-americanas, onde a relevância dessas questões fica patente; em segundo, uma apreciação de dois pares de monografias recentes, escritas por autores de gerações sucessivas, nos Estados Unidos e na Índia. Finalizo com uma agenda para o exame da antropologia em sua dupla face, singular e plural. 


\section{As livrarias norte-americanas}

Se hoje a antropologia feita nos Estados Unidos domina a cena internacional em quantidade e qualidade, servindo como indicador e termômetro para os antropólogos de outras latitudes, a visão de Fredrik Barth indica que o diálogo com os norte-americanos, ou melhor, com as obras e autores que adquiriram maior visibilidade e legitimidade social naquele contexto, é inevitável para todos nós 4 . Em suas manifestações variadas, a antropologia feita nos Estados Unidos parece ocupar atualmente um espaço socialmente equivalente àquele da Inglaterra na primeira metade do século, ou da França no período áureo do estruturalismo. No entanto, inserida em uma ambiência em que a idéia de fragmentação se transforma em valor, nos Estados Unidos a antropologia é inevitavel mente alvo de críticas e ameaças de dissolução. N as publicações especializadas, o bombardeio às disciplinas domina o campo das humanidades no mundo pós-moderno.

Curiosamente, esses indícios de que a antropologia foi um fenômeno do século XX ou, igualmente desolador, de que ela se tornou normal science, apenas reproduzindo velhos modelos, não se confirmam no cotidiano dos departamentos de antropologia5. Ali, a existência de múltiplas vertentes continua sendo uma das características mais marcantes na formação de novos especialistas, não tendo sofrido mudanças básicas. Ainda assim, observam-se algumas alterações: primeiro, modificaram-se os campos vizinhos da antropologia (como opositores ou aliados) - em vez da arqueologia, biologia, sociologia ou lingüística das últimas décadas, quando saem de seus departamentos os antropólogos hoje podem ser encontrados nos de história da ciência, crítica literária ou filosofia. Segundo, um espaço extra é reservado nos seminários de formação teórica a um tipo de leitura que familiariza o estudante com os recentes cultural studies. Utilizo o termo magia para indicar o poder e o perigo associados a essas novidades primeiro introduzidas na década de 70 pelos programas de history of consciousness, nos anos 80 pela abordagem dos cultural studies e, mais recentemente, pelos programas de science, technology and society ${ }^{6}$. A polêmica que envolve essas áreas, mesmo nos Estados Unidos, não impede que essas tendências sejam incorporadas na transmissão da disciplina; mas talvez por estimular demais, os professores mais zelosos supervisionam a absorção dessa literatura, incluindo-a no final dos cursos obrigatórios, depois de lidos os clássicos.

Se as universidades refletem algumas mudanças, o locus etnográfico privilegiado para apreciá-las não são nem os departamentos nem os 
programas de vanguarda, mas as livrarias7. Nos Estados Unidos, as livrarias acadêmicas são aqueles lugares especiais - templos, de certa forma - que, existindo entre a avidez do conhecimento e o poder do mercado, devem sua sobrevivência ao espírito de circulação e reprodução que também rege o mundo acadêmico. Boas livrarias necessitam manter um estoque tradicional/clássico, mas, especialmente, precisam exibir novidades e antecipar novas tendências.

Hoje, circular por uma boa livraria acadêmica norte-americana indica de imediato o estado de liminaridade que antecipa o novo século. Se o século XIX terminou em 1914 na Europa9 ${ }^{9}$, nos Estados Unidos o atual milênio já tem seus dias contados. Alguns começaram mais cedo, como o projeto do anuário antropológico Late Editions, mas dicionários e enciclopédias já fazem o balanço dos últimos cem anos ${ }^{10}$. Tempo e espaço mudaram nas livrarias, e a reorganização das áreas de conhecimento seguiu a redistribuição espacial das estantes. A antropologia, que nunca ocupou lugar de destaque, perdendo sempre para a ciência política, economia e sociologia, agora parece se esconder em recantos ainda menos visíveis. A primeira impressão é a de que os livros estão fora de lugar, migrados para outras áreas. O caminho que levou esses livros de antropologia para as estantes de cultural and critical theory, e destas para as de filosofia e ciência, não demorou mais de uma década ${ }^{11}$. N esse processo há outras surpresas. Publicações de um só autor podem ser classificadas em diferentes categorias: por exemplo, Homo Hierarchicus fica em Asia/Pacific, enquanto German I deology, em filosofia. As chamadas antidisciplinas são indexadas pela presença do termo studies (media studies, feminist studies, science and technology studies, cultural studies), e tornam-se áreas de ponta12. Enquanto isso, filosofia e ciência continuam a dividir o prestígio maior, mas hoje o termo ciência compreende, ao mesmo tempo, conhecimento, crença e crítica (além de etnografia, como veremos).

Nesse contexto fragmentado, de forma (in)esperada, distinções político-geográficas (ou culturais) sobrevivem com vigor renovado. Esse tipo de definição, em muitos casos, supera a classificação por áreas de conhecimento: assim, monografias antropológicas recentes, como Writing Women's Worlds. Bedouin Stories (de Lila A bu-Lughod), encontram-se em Middle-East; Debating Muslims (de Michael Fischer e M edhi Abedi), em Islamic Studies; e, em Latin A merica, o destaque é para Death without Weeping (de N ancy Scheper-Hughes) ${ }^{13}$. Finalmente, para o visitante ocasional, a surpresa maior: disciplinas tradicionais foram renomeadas ou desapareceram - lingüística, por exemplo, é categoria inexistente hoje porque se transformou, nos últimos anos, em cognitive science. 
Nesse processo de deslocamento e fragmentação, nas livrarias a antropologia tornou-se ela própria um fenômeno pós-moderno, multisited ${ }^{14}$, e não seria exagerado se temer uma vitória de Pirro: hoje transformada em senso comum intelectual - como no caso da psicanálise algumas décadas antes - , não teria a antropologia perdido sua especificidade social e cognitiva? Este parece ser um componente central da atual crise de identidade da antropologia nos Estados Unidos.

Felizmente, a antropologia nunca esteve limitada aos antropólogos e tem aparecido, como concepção e prática, em contextos diversos, sob o manto da filosofia, sociologia, folclore, história, crítica literária, e até nos atuais cultural studies. Às vezes, ela é parte das humanidades; outras, das ciências sociais. Na Índia, os antropólogos se autodenominam sociólogos; no Brasil, a antropologia nasce da sociologia15. No entanto, no processo de absorção seletiva das vogas intelectuais, historicamente convivemos com as ansiedades dos centros metropolitanos - e às vezes partiIhamos delas - que, por um tempo, pretenderam chegar a uma definição da disciplina16. Hoje, diante da decretada autodissolução, mas cientes da relativa continuidade das ideologias e das instituições, a discussão sobre o fim da antropologia talvez possa ser melhor formulada por intermédio das indagações: onde está a antropologia? Onde será que ela emerge? Talvez seja preciso um contexto tão sensível às classificações acadêmicas como o norte-americano para gerar esse tipo de oposição reativa: não apenas pós (como em pós-modernas), mas também multi (como em multiculturalismo), anti (como em antidisciplinar) e pré (como em précientífico, pré-categórico, pré-psicológico, pré-sociológico) ${ }^{17}$. Mas, para nossa tranqüilidade, embora a antropologia esteja sob suspeita, Clifford Geertz ainda se considera um antropólogo18.

\section{Intervalo: anthropology at home}

Durante muito tempo a antropologia se definiu pelo exotismo do seu objeto de estudo e pela distância, concebida como cultural e geográfica, que separava o pesquisador do grupo pesquisado. Cabia a outras ciências sociais, como a sociologia, e mais tarde a ciência política, o estudo da sociedade do próprio cientista social.

Esse quadro mudou. Ao longo deste século, as distâncias que separavam o etnólogo do seu grupo foram se tornando cada vez menores, com o questionamento inevitável do pronome possessivo (meu/seu): dos Trobriandeses para os Azande, destes para os Bororo, passando pelos Kwa- 
kiutl, na década de 60 a comunidade acadêmica descobriu que era a abordagem, e não o objeto de estudo, que, desapercebida, havia sempre definido o empreendimento antropológico. Lévi-Strauss desempenhou papel fundamental nessa mudança de consciência, passando a imprimir um sentido horizontal às crenças e práticas sociais em qualquer latitude. Daí em diante, o projeto durkheimiano do início do século pôde-se afirmar, por vários caminhos, até que Geertz, na década de 80 , proclamou como original a idéia de que "agora somos todos nativos", o outro podendo estar além-mar ou no fim do corredor19. Depois da longa tradição em que o fazer antropológico tinha como aspecto distintivo as distâncias cultural e geográfica, a etnografia foi trazida para casa, apesar das admoestações da geração mais velha20. Mas a legitimidade de se pesquisar em casa precisou dos estudos de parentesco como o ácido teste de validade e, talvez não seja por acaso que, mesmo com abordagens diversas, Raymond Firth, na Inglaterra, e David Schneider, nos Estados Unidos, tenham se destacado como pioneiros nessa tarefa (Firth e Djamour 1956; Schneider 1968).

É bem verdade que aos antropólogos que eram/foram também nativos se dispensou, desde os primórdios da disciplina, a procura da alteridade radical. Assim, em 1939, Malinowski deu o aval para Hsiao-Tung Fei publicar sua monografia sobre os camponeses chineses:

\footnotetext{
"The book is not written by an outsider looking out for exotic impressions in a strange land; it contains observations carried on by a citizen upon his own people. It is the result of work done by a native among natives. If it be true that self-knowledge is the most difficult to gain, then undoubtedly an anthropology of one's own people is the most arduous, but also the most valuable achievement of a field-worker" (Malinowski 1939:xix).
}

Se Malinowski nos surpreende por sua postura ousada, ele não estava sozinho. A aprovação que Radcliffe-Brown e Evans-Pritchard deram ao estudo de M. N. Srinivas sobre os Coorgs indianos sugere que o cânone pode ter se desenvolvido independente das práticas ${ }^{21}$. $\mathrm{O}$ ideal da pesquisa além-mar, contudo, permaneceu como meta a ser alcançada, a tal ponto que, décadas depois e inserindo-se em uma tradição que sistematicamente questionou a necessidade da pesquisa de campo externa, em 1982, Satish Saberwal concluía que a pesquisa de campo na Índia era uma soft experience, já que realizada na própria língua, casta, e na região de origem do pesquisador22.

No caso dos pesquisadores de tradições ideologicamente centrais, que só mais recentemente passaram a aceitar que também são nativos, 
as motivações que os levam a trazer a antropologia para casa variam: para alguns, trata-se das condições inevitáveis do mundo moderno; para outros, surge do propósito de transformar a antropologia em "crítica cultural" 23. É nesse contexto que podemos retornar aos cultural studies para sugerir uma afinidade entre as atuais arenas antidisciplinares e uma antropologia realizada at home. Incluo aí as diversas manifestações sob as quais a antropologia emerge, como feminist studies, media studies, cyborg studies etc. Quando volta para casa, a antropologia nos Estados Unidos fragmenta-se em studies. Em 1986, M arcus e Fischer deixavam entrever essa relação:

"Indeed, we believe that the modern formulation of cultural anthropology depends for its full realization on just such a catching up of its lightly attended to critical function at home with the present lively transformation of its traditionally emphasized descriptive function abroad" (M arcus e Fischer 1986:4; ênfase minha).

Se nas décadas de 50 e 60 o modelo da lingüística havia servido de inspiração para os antropólogos, agora era a crítica literária a nova fonte. Em casa e assumindo uma função crítica, bombardeando as fronteiras das disciplinas e propondo um remapeamento das áreas de conhecimento, essas atitudes levaram à denúncia da validade dos "fatos" e da autoridade do antropólogo como autor ${ }^{24}$. Nesse contexto, a antropologia passou a dispor de um novo elenco de alternativas literárias legítimas e politicamente adequadas: notas de campo, biografias, entrevistas, ficção científica, romances, manifestos - todas elas constituindo-se em novos estilos do gênero mais abrangente de estórias (stories)25.

De forma inevitável, esse movimento se refletiu no mundo acadêmico mais amplo mediante um processo seletivo de incorporação. M as aqui deixo a proposta de que, talvez equivalente ao aspecto político que o gênero de stories adquiriu nos Estados Unidos, em lugares como Índia e Brasil predomina a análise de eventos socialmente relevantes. Eventos mantêm aquela dimensão social poderosa que antes os dramas sociais e os rituais instigavam nos antropólogos; eles são recriados no texto na tentativa de capturar o instante vívido, perdido e crucial que o narrador presenciou (ou que se tornou significante). Mais: na análise de eventos, objetivos teórico-intelectuais e político-pragmáticos tornam-se coincidentes; não há culpa pela inspiração clássica (ou, ao contrário, pela influência pós-moderna), e o universalismo mistura-se aos aspectos “interessados" daqueles que sempre desenvolveram antropologia em casa. 
N aturalmente, eventos não são descartados nos Estados Unidos mas lá, às vezes, eles são ficcionais -, e relatar estórias é opção de muitos antropólogos indianos e brasileiros ${ }^{26}$. M as há de se confrontar as dimensões teóricas, interpretativas e políticas que essas alternativas implicam. A comparação entre as duas estratégias pode ser ilustrativa em termos sociológicos porque diz respeito não só à questão de uma antropologia em contexto, mas remete ao tema fundamental de como discernir e apresentar o fato tangível que orienta a etnografia e resulta da pesquisa. Aqui, passo para a segunda parte deste exercício, confrontando dois pares de livros de autores indianos e norte-americanos. Estes livros foram publicados nos últimos três anos: de uma primeira geração, escolhi After the Fact (Geertz 1995) e Pathways (M adan 1994); da geração seguinte, Critical Events (Das 1995a) e Making PCR (Rabinow 1996).

\section{Estórias e trilhas}

After the Fact, de Clifford Geertz, e Pathways, de T. N. M adan, são livros tangencialmente autobiográficos, o que de imediato indica a consciência de seus autores da influência que exerceram no desenvolvimento da antropologia. É inegável que Clifford Geertz tem maior visibilidade em termos internacionais, $M$ adan sendo mais reconhecido entre os que freqüentam a literatura etnográfica pertinente à Índia, incluindo a antropologia francesa da linhagem de Louis Dumont27. A publicação paralela de ambos, em dois contextos diversos, é reveladora.

Sensíveis e alertas à forma do texto, os dois autores antecipam os primeiros contrastes no tipo de construção que adotam. Para Geertz, neste momento em que mudam o meio intelectual e a base moral nos quais a antropologia se apóia, o antropólogo também se modifica e hoje conta com a alternativa das mininarrativas que incluem o narrador como opção literária28. Seguindo esses novos ventos, After the Fact reúne peças de um refinado contador de estórias que, pinçadas à maneira de um vasto caderno de campo, servem de base para o autor discutir temas candentes. No estilo conhecido, os títulos dos vários capítulos são compostos de uma só palavra, todas no plural. A seqüência Towns, Countries, Cultures, Hegemonies, Disciplines, Modernities por certo não é aleatória (por exemplo, a ordem towns/countries/cultures permeia a disciplina; politicamente adequado, Hegemonies antecede Disciplines, e tudo termina em M odernities). Da mesma maneira, todas as referências bibliográficas 
estão reunidas em notas que inexistem no corpo do livro, mas são apresentadas ao final como comentários. ${ }^{29}$ Nesse livro impecável, Geertz não apresenta uma história nem uma biografia, mas "uma confusão de estórias, uma profusão de biografias".

Da Îndia, Pathways também fala das mudanças no mundo, das disciplinas, das culturas e das modernidades, mas a opção de Madan direciona-se para uma etnografia intelectual que tem como ponto de partida as trilhas intelectuais e, como estratégia geral, a questão da inserção, nelas, do cientista social. É a definição da perspectiva a partir da qual o antropólogo se introduz no mundo da reflexão social e nas trilhas existentes que preocupa o autor. Dois blocos dividem o livro: "Pathfinders" é dedicado aos antecessores com quem $\mathrm{M}$ adan se associou em determinado momento de sua trajetória e que terminaram por influenciar seu trabaIho. Tratando-se de um pesquisador indiano, os personagens são de várias origens e linhagens intelectuais: M ukerji, M ajumdar e Srinivas, do próprio subcontinente; Dumont, o outstanding pathfinder que assume o legado de M arcel Mauss; e os norte-americanos, de Kroeber ao contemporâneo M cKim M arriott. "In search of a path", a segunda parte, é mais pessoal e reflexiva: um conjunto de ensaios sobre pesquisa de campo em contextos nativos permite um corajoso exame da relação entre a antropologia e o processo histórico de racionalização do Ocidente; um outro ilustra a abordagem teórico-comparativa de interpretação mútua. Aqui, a questão do pluralismo cultural, candente para a Índia, é focalizada por meio de três temas empíricos e contrastantes, relacionados às várias etnias e a vários momentos da história indiana30.

Escritos maduros de dois etnólogos que vivenciaram as últimas décadas de ângulos diversos, suas visões particulares sobre a antropologia estão impressas em seus respectivos trabal hos. M as é interessante procurar, de novo, onde elas estão impressas. Para Geertz, por exemplo, a controvérsia acerca da noção de disciplina faz com que ele reconheça que a antropologia sempre foi pouco definida, oferecendo mais a blurry image que um model o foucaultiano. M as o tema o provoca, porque o faz perguntar se isso é um escândalo ou uma força. De qualquer modo, não podendo dizer "what anthropology is" (Geertz 1995:99), Geertz opta por examinar sua carreira acadêmica, com ênfase nas instituições de que fez parte, nas pesquisas de campo que realizou nos extremos da Indonésia e do $M$ arrocos, e no contexto mundial da época - o que traz como implicação um exame discreto do papel dos Estados Unidos na política internacional. Nesse percurso, dos tempos de estudante em Harvard, passando por Chicago nos anos 60, e depois Princeton, revela-se uma trajetória 
sempre vinculada a experimentos multidisciplinares, mas com elos nos departamentos de antropologia. Sua trajetória, relatada por meio de pequenas estórias e casos pitorescos (mas também de episódios nebulosos, como o Bellah Affair), leva-o finalmente a refutar a idéia de disciplina. Assim, se é na vida profissional que o antropólogo pode ser encontrado, essa é feita de indefinições e indecisões:

"The sequence of settings into which you are projected as you go if not forward at least onward, thoroughly uncertain of what awaits, does far more to shape the pattern of your work, to discipline it and give it form, than do theoretical arguments, methodological pronouncements, canonized texts. [...] You move less between thoughts than between the occasions and predicaments that bring them to mind" (Geert 1995:134)31.

Caminho oposto é o de T. N. Madan. Embora também reconheça as ocasiões e os predicamentos - que elabora nas estórias e casos de trabaIho de campo -, M adan faz das trilhas (pathways) o nódulo central de seu argumento e, da posição do antropólogo, a base de sua discussão. Insinuando o tema da disciplinaridade, $\mathrm{M}$ adan reconhece $\mathrm{o}$ aspecto sociológico das trilhas, mas deixa claro que criatividade e trilhas intelectuais não são excludentes ${ }^{32}$. Se não há exatamente descobertas na antropologia, mas tentativas renovadas, estas só têm a ganhar com as diversas situações nas quais o pesquisador pode se encontrar: o treinamento a que se submete faz o antropólogo viver o estranhamento mediante o contraste entre a literatura em que se formou e a expectativa empírica de ser surpreendido - que tanto pode ser na Índia quanto alhures - , em qualquer circunstância, confrontando idéias preconcebidas. Um antropólogo não-ocidental, portanto, não é um pseudo-europeu por natureza, alguém que adotou uma das muitas maneiras de se tornar europeu. Como o encontro de culturas se dá na mente do antropólogo, os propósitos de compreensão mútua, o projeto de uma critical self-awareness ou, ainda, an effort to see in the round what otherwise is flat guiaram-no mais que o conhecimento da pura alteridade. Madan alerta: "an excessive emphasis on the otherness of those studied only results in their being made the objects of study rather than its subjects" (Madan 1994:159). Paradoxalmente, na Índia, a própria antropologia contribuiu para a disseminação de imagens rígidas sobre sua constituição, como exemplificam o papel do carma, da casta e da renunciação. Dada essa visão antropológica importada, os indianos precisaram recuperar os idiomas locais da responsabilidade moral, da família, da plenitude e da auspiciosidade33. 
Aqui do Brasil, é curioso notar que um importante evento na trajetória de T. N. M adan recebe apenas discretas indicações em seu livro: trata-se do papel que desempenhou na mudança da revista Contributions to Indian Sociology da Europa para a Índia. Essa mudança ocorreu no momento em que Louis Dumont (École des Hautes Études) e David Pocock (Oxford), os fundadores europeus de 1957, decidiram encerrar a publicação. Foi quando uma complexa negociação permitiu seu renascimento na Índia e M adan tornou-se o responsável por essa importante revista nos 25 anos que se seguiram, de 1967 a 1992, criando ali um fórum privilegiado de discussão e debate. Os papéis pedagógico, teórico e político que a transmigração da revista acarretou, tanto na Índia quanto no exterior, são um importante legado da carreira de T. N. Madan que só surge em Pathways como subtexto ${ }^{34}$.

De forma equivalente, um importante subtexto de After the Fact diz respeito à contribuição individual de Geertz para a antropologia. Embora temeroso das várias implicações disciplinares, Clifford Geertz reconhece, na sua trajetória individual, as conseqüências de ser um cidadão norteamericano ("There are lots of advantages in being the citizen of a superpower in less prominent places, but cultural invisibility is not among them"), tanto quanto sua própria notoriedade ("in 1980, when, cited all over the place, my contributions were dissected, resisted, corrected, distorted, celebrated, decried, or built upon [...]") (Geertz 1995:98). Quando o autor admite que se tornou referência obrigatória, After the Fact deixa de ser a narrativa de uma carreira individual e torna-se - queira ou não seu autor (e talvez o queira...) - um capítulo da própria história da antropologia. Depois de demonstrar, pelas evidências de sua trajetória, que a antropologia está sempre em transformação, Geertz menciona como sui generis as mudanças atuais: a inquirição a que os antropólogos são submetidos por parte de outros especialistas (em contraste com os velhos tempos, quando o etnólogo dominava sozinho o campo); o escrutínio ainda maior por parte de antropólogos locais; e o aumento significativo do número de especial istas nos Estados Unidos ${ }^{35}$. Antes uma ocupação restrita a poucos que se comparava a uma tribo, "anthropology has become a sprawling consortium of dissimilar scholars held together largely by will and convenience" (Geertz 1995:133).

Por contraste, T. N. M adan contesta tanto as verdades ocidentais quanto os projetos que vêm previamente empacotados com os nomes de native, spontaneous, autonomous ou indigenous. Para ele, estes últimos distorcem a natureza da antropologia e só reforçam a opinião de que o aparecimento do antropólogo nativo nada muda: 
"The crucial question is not Who is doing anthropology? but What kind of anthropology is being done? A mere change of the stage and the actors will not enable anthropology to be reborn. [...] we need to produce a different kind of play under the direction of comprehensive theoretical frameworks, which admit meaning and purpose into our discourse, and which integrate the view from the inside with those from the outside" (Madan 1994:138-139).

Dois livros, dois balanços autobiográficos; estórias individuais de um, trilhas coletivas para outro. Para Geertz os eventos únicos não se somam em uma disciplina; se sua biografia é construída de ocasiões e ela é índice do que ocorre entre os especialistas, torna-se possível dessa perspectiva pensar que a antropologia se resume apenas a uma vaga coleção de carreiras intelectuais. M adan parte da própria conjunção de carreiras intelectuais, sociologiza as trilhas, insere-se no emaranhado delas e, dispensando a discussão sobre a disciplinaridade da antropologia, oferece seu livro aos leitores que simpatizam com a idéia de que "no author is an island complete unto himself; [...] every scholar has predecessors, consociates, and successors" (Madan 1994:ix).

\section{Eventos e estórias}

No prazo de uma década é possível que os balanços de então revelem como, na antropologia, o final do século foi marcado pelo retorno da disciplina ao seu ponto social de origem. A pesquisa at home substituiu o ideal canônico do encontro radical com a alteridade. "Indeed", lembra Geertz hoje, "an increasing number of us work on Western societies, and even our own; a move which simplifies some matters and complicates others" (1995:132). A consciência de que nunca se saiu totalmente de casa talvez fique explícita: que a África era parcialmente home para os britânicos quando eles exportaram a idéia de totalidade para as colônias ${ }^{36}$; e que hoje um processo de incorporação seletiva legitima, nas metrópoles, especialistas originários de antigos sítios antropológicos que integraram conhecimentos antes considerados nativos ${ }^{37}$. A comparação entre Critical Events (de Veena Das) e Making PCR (de Paul Rabinow) revela que, enquanto na Índia a pesquisa deve avaliar a própria sociedade e também a antropologia, nos Estados Unidos a pesquisa politicamente comprometida tem a ciência como objeto - isto é, em termos durkheimianos, a ciência é a sociedade - e a antropologia transforma-se em categoria residual. Vejamos. 
Critical Events, de Veena Das, é composto de ensaios sobre variados temas e tempos: o rapto de mulheres, tanto por hindus quanto por muçulmanos, nos conflitos que marcaram a independência da Índia e a formação do Paquistão; a análise de um caso recente da prática de sati (quando a viúva segue o marido na pira que o cremou) e os debates que suscitou; uma reflexão sobre a violência do discurso militante sikh; o exame das várias dimensões do desastre químico de Bhopal. Veena Das parte de uma dupla posição: esses eventos identificam momentos cruciais na história da Índia contemporânea, e el es são, então, reanalisados a partir de um quadro de referência da antropologia. Aqui, a expressão "na história da Índia contemporânea" ilumina a idéia de eventos como momentos críticos que, a partir de uma estratégia que procura evitar o privilégio da localidade, substitui tempo por espaço e, nesse cruzamento, quer "dessencializar" a Índia.

M as também a reconstrói. No desenrolar do livro, Veena Das reúne como indianos os eventos ocorridos entre hindus, muçulmanos e sikhs; contesta e reavalia valores aceitos da modernidade (por exemplo, os direitos humanos e a compreensão da dor); procura contribuir para uma mudança na metanarrativa indiana do Estado nacional, alertando para o perigo de valorizar-se indevidamente a comunidade como unidade orgânica e autêntica - já que ela também tem seus meios de opressão. O projeto de Veena Das termina por atingir outros objetivos: por exemplo, mostrar como os vários planos (local, nacional e global) podem estar presentes, de forma simultânea, na vida de um só indivíduo; tornar evidente a verdade das vítimas da violência política; e propor uma antropologia da dor que, mais que consolidar a autoridade da disciplina, tem como objetivo reabilitar, dar voz e permitir que as vítimas da violência sejam abraçadas $^{38}$. No processo, a autora esclarece sua própria visão das trilhas intelectuais (para usar a expressão de T. N. M adan) e sua inserção nelas.

Para Veena Das, há no mínimo três ângulos que definem a etnografia na Índia: um, o diálogo com as tradições ocidentais; outro, com o sociólogo ou antropólogo indiano; e, um terceiro, com o informante, cuja voz está presente como informação obtida no campo ou nos textos escritos da tradição. Esses diálogos permitem uma compreensão mais clara da inserção da autora: em primeiro lugar, para Veena Das o informante é a vítima, a quem se deve dar voz ${ }^{39}$. A preocupação de Madan de abrandar a alteridade encontra paralelo aqui na proposta de dar ao informante o status de primeira pessoa (e evitar a terceira). A autora substitui a metáfora do ol har (gaze), que teria marcado a antropologia neste século, pelo ouvir, explicitando nesse momento a influência, na sua abordagem, da pers- 
pectiva pós-moderna ("the new forms of ethnographic writing sensitive to the inner lives of subjects" (cf. Das 1995:18).

M as a construção do livro também dá ciência do diálogo com pares indianos de maneira marcante: a escolha da dedicatória a M. N. Srinivas é extremamente relevante. Srinivas, o decano da antropologia na Índia, por muito tempo foi criticado por suas visões colonizadas, mas Veena Das o resgata no contexto de uma aliança com os subaltern historians e com o tradicionalista A. K. Saran, para que todos, com abordagens diversas, mas juntos, se somem na crítica ao suposto elitismo de Louis Dumont ${ }^{40}$. É Louis Dumont, afinal, quem perturba e quem provoca a dor na antropóloga, revelando sua vulnerabilidade ${ }^{41}$ :

“I reiterate my admiration for [Dumont's] remarkable abilities in bringing together a wide range of materials within a single theoretical frame, but my admiration for his achievements cannot take away the pain that an encounter with his formulations entails for an anthropologist who wishes to lay claims to both - the resources of the anthropological tradition and the Indian tradition, both of which can act as global traditions or local traditions" (Das 1995:33, nota 5; ênfases minhas).

Erra, contudo, quem pensa que Veena Das se alia aos indianos por oposição aos ocidentais. Além da aliança com os pós-modernos, é em Wittgenstein que Veena Das encontra inspiração para compreender que a dor é uma queixa, e em Durkheim a lição de que a participação na dor serve como base para uma comunidade moral ${ }^{42}$. Entre as fontes da tradição antropológica ocidental, de um lado, e a inspiração indiana, de outro, Veena Das faz uma triangulação com antropólogos de outros espaços periféricos e aí, num esforço de pluralizar as narrativas da disciplina e eliminar seu eurocentrismo dominante, uma al iança com a antropologia no Brasil é proposta. Desse processo resulta uma multiplicação de trilhas intelectuais que oferece a oportunidade de expandir o diálogo empreendido sobre a Índia43. (Em termos de visibilidade, Critical Events foi considerado "O Livro do Ano de 1995" na Índia; sua autora foi homenageada no Vega Day Symposium de 1995, na Suécia. ${ }^{44}$

Nos Estados Unidos, o quadro é bem diferente. Tomando M aking PCR. A Story of Biotechnology de Paul Rabinow como exemplo, aí não se encontram interlocutores próximos. Se há dez anos os antropólogos chamados pós-modernos podiam ser reconhecidos sociologicamente pelas citações mútuas, o novo livro de Paul Rabinow indica que a época dos experimentos já acabou nessa vertente. A área revela-se consolidada por 
um indício crítico: Rabinow não cita seus companheiros de aventura intelectual. O autor reserva aos colegas um agradecimento e uma desculpa: os agradecimentos estão no final do livro, e incluem os colegas e especialistas que vêm realizando trabalhos na área; a desculpa é por não citar as publicações desses colegas na bibliografia que vem a seguir. As triIhas, aqui, foram apagadas.

"I regret that it is inappropriate to include more explicit citations to the lively debates of these fields; keen and tolerant readers will find traces abound. I trust that my colleagues will realize that this book seeks a somewhat broader audience, including some who are far less tolerant of the technical language of science studies" (Rabinow 1996:175)45.

Cabe ao leitor arguto, inteligente e bem informado reconstituir, se puder, os debates que o autor faz questão de não revelar ${ }^{46}$. N esse texto Rabinow examina uma das grandes invenções da ciência contemporânea: a PCR (polymerase chain reaction) que, tornada exemplar na área da biotecnologia, estendeu a capacidade de identificação e manipulação de material genético para uma escala antes inconcebível.

O livro inclui uma análise do estado da biologia molecular, do contexto institucional no qual a invenção ocorreu e dos principais atores envolvidos: cientistas, técnicos, industriais. Com um subtítulo instigante (A Story of Biotechnology), é significativo que a etnografia tenha uma estrutura clássica ${ }^{47}$. Os dois primeiros capítulos apresentam, o primeiro, a ecologia da invenção mediante uma avaliação do caminho experimental e conceitual que desembocou na biotecnologia e, o segundo, um exame da Cetus Corporation, onde os experimentos foram conduzidos. O (sempre nobre) terceiro capítulo focaliza o processo que levou à invenção propriamente dita, unindo o meio experimental e o conceito; os dois últimos demonstram que uma idéia tem pouco valor se não é colocada em ação. Ali, trata-se de relatar o desenvolvimento do conceito, o processo que deu visibilidade científica à PCR, os conflitos entre membros da equipe e as negociações entre companhias de grande porte.

O relato elegante e sóbrio tem como maior novidade na construção etnográfica a inserção de várias entrevistas que pontuam os capítulos. Essas conversas (que tiveram na revisão a co-autoria dos entrevistados) fornecem ao leitor uma janela para o mundo que o etnólogo descreve e, pela afinidade com situações vividas por um leitor acadêmico, se tornam particularmente reveladoras: a avaliação das desvantagens do mundo acadêmico vis-à-vis o industrial, os critérios e meios para se conseguir 
recursos para pesquisa, as regras de legitimação e prestígio no mundo industrial-científico, a necessidade da avaliação pública, as personalidades, idiossincrasias e vida pessoal dos cientistas. M as um subtexto importante está na seqüência da construção etnográfica, que vai do conceito ao sistema experimental, deste ao desenvolvimento das técnicas e, de volta, a um novo patamar conceitual que, revelando o moto-contínuo do mundo da ciência experimental, nos relembra algumas monografias da antropologia, assim como fornece as condições para a compreensão da reprodução social desse setor no mundo da biotecnologia.

E aqui está o ponto crítico. Making PCR, ao mesmo tempo que sugere uma proposta textual a partir de uma estória, revela a inspiração antropológica clássica no gerúndio do título - trata-se, portanto, de um experimento realizado nos Estados Unidos de hoje, at home, tanto na ciência, transformada em objeto, quanto na apropriação da tradição pelo pesquisador solitário. Duplamente em casa, Rabinow revela sua motivação inicial:

"I was often intrigued by, but skeptical of, the claims of miraculous knowledge made possible by new technologies supposedly ushering in a new era in the understanding of life and unrivaled prospects for the improvement of health. The weekly New York Times science pages rarely failed to announce that every new discovery or technical advance 'could well lead to a cure for cancer or AIDS'" (Rabinow 1996:2).

Ali é a ciência nobre que, por sua promessa mágica, chama a atenção do pesquisador. E, ao fazer a antropologia voltar para casa, a etnografia da ciência torna-se a denúncia da pós-modernidade - nesse momento realizando o projeto durkheim/maussiano, mas afirmando sua opção como política. No processo, Rabinow reforça também mais um aspecto canônico da antropologia: o de que, mesmo em casa, o etnólogo precisa aprender uma língua nova - a da biologia molecular - , deixarse socializar por um longo período e, como sempre, questionar "quem tem a autoridade e a responsabilidade de representar a experiência e o conhecimento" (Rabinow 1996:17).

N esse contexto, é curioso que o livro não cite a etnografia sobre os físicos de alta energia que Sharon Traweek (1988) publicou nos Estados Unidos $^{48}$. Optando pelo diálogo particular com um clássico distante, o livro abre e fecha com uma discussão de "A Ciência como Vocação": o estranhamento em casa talvez precise da legitimação que Weber dá ao empreendimento, com o bônus da peculiaridade que ele concedeu aos 
Estados Unidos ${ }^{49}$. A relação com Lévi-Strauss é igualmente singular: não só por se tratar do único antropólogo citado, mas porque é na bricolagem e no mouvement incident que a estória da biotecnologia, que Rabinow conta, se transforma, nas últimas páginas do livro, em "Event". As revoluções científicas são, afinal, bricolagens: um jovem (e naturalmente controvertido) cientista teve a idéia de fazer uma conexão entre suas pesquisas com DNA e experimentos com fractais e programas de computação - descobriu que o resultado era exponencial e a PCR tornou-se aquela simple little thing para o prêmio Nobel Kary Mullis.

$O$ poder de fazer emergir eventos sem precedentes e verdadeiras revoluções científicas faz parte de um jogo social, mas essas revoluções precisam de outros participantes que coloquem a invenção em uso. Essa constatação de Paul Rabinow, contudo, não é reconhecida pelo autor na natureza da disciplina que o informa; se há um antropólogo aqui, não existe, por implicação, uma antropologia. Testemunhamos então, mais uma vez, o movimento que, na biotecnologia como na antropologia, faz o conceito retornar, a estória contada se transformar em evento, e o conceito continuar a produzir outros fenômenos através de novas contextualizações, gerando mais invenções. (De forma reveladora, mas não surpreendente, nas livrarias acadêmicas norte-americanas o livro de Rabinow não se encontra classificado em antropologia nem cultural studies, mas nas prateleiras de Science.)

\section{"Ce qui est donné"}

Um "livro do ano", uma invenção da "ciência"; eventos que são história, estórias que acabam no evento - estas são várias maneiras como a antropologia pode emergir em diferentes lugares no mundo contemporâneo. Às vezes, vinculadas a trilhas intelectuais; outras, a mininarrativas biográficas que não reconhecem linhagens disciplinares. Mas como distinguir as várias opções de construção teórico-etnográfica?

Neste exercício, que teve na publicação de quatro livros seus próprios eventos, vemos que a delimitação do relato e o privilégio do momento etnográfico decisivo são problemas centrais como sempre: Veena Das descobriu os momentos críticos questionando visões totalizadoras e assumindo mais o papel de ouvinte que o de observadora; Paul Rabinow contou a estória de uma invenção científica - mas inseriu entrevistas que trazem os protagonistas como co-autores da narrativa; lá, nos Estados Unidos, os relatos nativos não precisam mais de tradução. Os eventos de 
Veena Das são indianos; eles são socialmente críticos na história do subcontinente, e a autora insere-se em trilhas intelectuais que incluem múltiplos interlocutores: europeus, indianos, brasileiros. A estória da biotecnologia de Paul Rabinow não apresenta evidência das muitas linhagens nas quais se inclui; trata de um evento de conseqüências globais; e o autor dispensa o diálogo interpares, elegendo como principal interlocutor um clássico que, no contexto de um livro que evita definições disciplinares, detém o privilégio da distância no tempo e espaço.

A estória se repete, embora nunca seja a mesma: antes, Geertz pôde dispensar antecessores em nome de uma trajetória biográfica única, mas M adan definiu-os para balizar sua própria procura; Geertz percorreu instituições e sítios de pesquisa em uma mobilidade que, em termos simbólicos, abarcou o mundo, mas M adan definiu sua posição da Índia, mesmo negando o papel de indigenous e incluindo uma linhagem que não conheceu barreiras: ao mundo político/geográfico de Geertz, M adan contrapôs outro feito de trilhas intelectuais. Rabinow encontrou seu evento na ciência universal, Veena Das definiu os seus social e historicamente da Índia; Rabinow quis saber mais sobre os processos sociais que as grandes descobertas científicas não deixam à vista, Veena Das interessou-se pelos limites do sofrimento das vítimas da vida coletiva - inclusive aquele que resulta das grandes descobertas.

Indianos e norte-americanos, de uma ou de outra geração, todos produziram narrativas legítimas para a comunidade internacional de especialistas. Isso foi possível porque os autores se posicionaram diante de determinadas histórias teóricas: contra ou a favor, inserindo-se ou negando, como elos ou autônomos. Se Veena Das mostrou sua inquietude em relação a Louis Dumont, mesmo evitando linhagens Paul Rabinow encontrou o pensamento selvagem de Lévi-Strauss em uma grande corporação industrial norte-americana. E se o comprometimento político levou Das a analisar eventos críticos a partir de uma perspectiva que ela quis multicentrada, o de Rabinow o fez contar uma estória da ciência na qual se incluiu como narrador.

Para o antropólogo, produzido e alimentado na pesquisa de campo, a articulação de experiências que vive e das quais participa, ou que reencontra como documento ou memória, de natureza, âmbito, abrangência e domínio diversos, precisa de uma âncora não apenas textual, mas cognitiva e psíquica que totalize a experiência. A apropriação do momento efêmero ou do incidente revelador tem nas experiências da disciplina os casos exemplares que levaram Mauss, depois de analisar o kula e o potlatch, a expressar assim sua preocupação: 
“Les historiens sentent et objectent à juste titre que les sociologues font trop d'abstractions et séparent trop les diverses éléments des sociétés les uns des autres. II faut faire comme eux: observer ce qui est donné. Or, le donné, c'est Rome, c'est A thènes, c'est le Français moyen, c'est le M élanésien de telle ou telle île, et non pas la prière ou le droit en soi" (Mauss 1925:182; ênfase minha).

Assim, dados são construídos, fatos são feitos. É o próprio Geertz (1995:62) quem lembra a etimologia factum, factus, facere. Mas dados derivam e partem de eventos empíricos. Quer os vejamos eles próprios como eventos reconstruídos no texto (Das), ou como estórias textuais (Rabinow), o que está realmente em jogo é a determinação do melhor ângulo para a construção do que é dado - de ce qui est donné. O fato de as variadas vertentes, modernas e pós-modernas, nem sempre iluminarem as implicações teórico-políticas em jogo, não elimina sua inclusão50. Estórias para uns, eventos e trilhas para outros, tal só reforça a presença de ângulos de inserção que são teóricos e políticos nas alternativas em questão. Trata-se de um problema que diz respeito ao que poderíamos denominar de "política da teoria" 51.

$\mathrm{M}$ ax Weber reconheceu, assim como M auss, a necessidade de delimitar e resolver problemas concretos contra "o diletantismo enfeitado de filosofia" (Weber 1992:157). Nessa ocasião, Weber também focalizou os vínculos entre o acaso, o evento e o fato histórico. Para Weber, da mesma forma que para os antropólogos hoje, reflexões puramente epistemológicas e metodológicas nunca contribuíram para o desenvolvimento das ciências da cultura. (Esse é mais um dos muitos ângulos de discussão que decorre das comparações anteriores e que, embora fascinante, fica aqui apenas registrado52.)

\section{De volta às livrarias}

Hoje, quando um leitor procura por livros de antropologia apenas nas prateleiras dessa área específica nas livrarias norte-americanas, ele se limita à literatura de estilo normal science. $\mathrm{Na}$ seção de antropologia estão aqueles livros considerados clássicos e, das publicações recentes, apenas aquelas que mantêm uma definição estável em que a antropologia é sinônimo de exotismo. Assim, nessa seção se encontram geralmente livros de autores canônicos, como Malinowski, Boas, M argaret M ead, Evans-Pritchard, Radcliffe-Brown, Lévi-Strauss etc.; coletâneas publica- 
das recentemente sobre temas consagrados (como ritual, religião, etnografia etc.); monografias sobre sociedades indígenas - independente de orientação teórica; e livros não tão recentes de autores celebrados que se tornaram legítimos como "antropólogos" (o exemplo mais evidente é M ary Douglas, mas inclui Clifford Geertz, de After the Fact).

Em termos dos livros aqui examinados, onde está a antropologia contemporânea? No que diz respeito a várias publicações novas, ela migrou para a área dos studies. Ou, então, para filosofia, cognitive science ou, puramente, Science - este último é o caso de Paul Rabinow. M as os livros novos podem também estar em seções especializadas em áreas geográficas que, ao dividir o mundo (A sia/Pacific, Latin America, M iddle-East etc.), as englobam em uma determinada cosmologia política. Esses vários lugares onde a produção antropológica encontra abrigo - corroborando a característica multi-sited da disciplina - remetem para uma questão central: o exotismo da antropologia. Hoje, ao pretender negar essa associação, os estudos de inspiração antropológica deixam de ser "antropologia": se existem antropólogos, a disciplina perdeu o fascínio. Mas, é justamente nesse processo que, de forma paradoxal, o exotismo se torna seu princípio estruturante.

A visita a livrarias confirma que a disciplina permanece tão associada ao exotismo (a despeito dos antropólogos) que até mesmo o mercado intelectual não consegue chegar à perspectiva moderna lévi-straussiana. O caminho parece seguir os seguintes passos: sendo a antropologia (ainda e sempre) o estudo do "outro exótico", nos anos 90 esse tipo de abordagem não é mais politicamente aceitável; volta-se então o ol har para o "nós" - isto é, para a alteridade próxima; nesse momento, para os antropólogos norte-americanos, o estudo deixa de ser antropologia e transforma-se em cultural studies, feminist studies, area studies, ou outra categoria. O resultado é inevitável: se a antropologia foi o estudo do "outro exótico", é porque, em termos de valores, ainda o é. Nesse processo, revelase a força da visão essencialista - e, portanto, a-histórica - no mundo intelectual norte-americano de hoje: ou uma disciplina é "disciplinada", isto é, sempre a mesma, ou desaparece.

Seria, contudo, simplista a visão de um mundo acadêmico norteamericano hegemônico e isolado, que dita categorias às quais o resto do mundo precisa se adequar. Aqui há um fato central que precisa ser indicado; ele diz respeito à introdução maciça de autores não-ocidentais no mundo intelectual e acadêmico de lá. Os quatro livros analisados dão um claro exemplo dessa mudança e, embora Veena Das e T. N. M adan não sejam tão facilmente encontráveis nas livrarias, a antropologia hoje pre- 
cisa admitir a inclusão de autores que um dia foram nativos - inclusive como elemento da cruzada contra a definição pelo exotismo53. A classificação de trabalhos de autores étnicos, e que foram absorvidos pelo mercado, revela caminhos característicos.

Tomo a idéia de intensificação emprestada de Louis Dumont. Para elucidar o caráter híbrido das aculturações modernas, Dumont identifica como as noções transplantadas tornam-se intensificadas quando comparadas àquelas de onde procedem - quer na vertente periférica, quer na própria configuração dominante e hegemônica (Dumont 1994:cap. 1). No caso dos livros em questão, esse mecanismo ocorre por deslizamentos de significado: mesmo com o subtítulo "An Anthropological Perspective on Contemporary India", Critical Events não pôde ser aceito como antropologia nos Estados Unidos; um antropólogo (nativo) que estuda sua própria sociedade não é um antropólogo, mas sociólogo. Por uma alteridade dupla (no caso, Índia \& antropologia), o livro desliza para sociologia um destino pouco favorável, aliás, nesse momento em que as disciplinas são questionadas 54 .

Já no Brasil, assim como na Índia, os livros After the Fact, Pathways, Critical Events e Making PCR são identificados como estudos antropológicos, tanto quanto são reconhecidos como antropólogos Geertz, M adan, Das e Rabinow. Não ocorre, nesses contextos, a pulverização disciplinar que hoje marca a área das ciências humanas nos Estados Unidos. Apesar da carga de simbolismo exótico e colonial que veio associada à antropologia, mecanismos internos de aculturação domesticaram, na Índia e no Brasil, por exemplo - bem antes que nos Estados Unidos - , a alteridade em casa. Poderia então se pensar que, cercada no "centro", a antropologia prospera em algumas "periferias", ou, se não prospera, pelo menos provê uma abordagem positiva, crítica e construtiva. Se o mundo moderno se constitui de processos de aculturação, esse seria um de seus vários aspectos irônicos.

M as outra situação relacionada ao exotismo, agora dos autores, diz respeito aos trabal hos que, provenientes de áreas diversas e escritos sob orientações teóricas divergentes, nos Estados Unidos são reunidos sob o rótulo mágico de cultural studies. Bem definidos em suas comunidades locais, os subal tern studies, a crítica literária (marxista ou não) e, às vezes, até mesmo a antropologia, quando ancoram nos Estados Unidos, recém-chegados da Índia, perdem suas características distintivas. M ais uma vez, a designação genérica de cultural studies evidencia a tendência atual de fragmentar os campos intelectuais para depois reunir os diferentes como análogos, eliminando, dessa forma, as particularidades 
(que são históricas e, portanto, nacionais) em nome de uma compartilhada pós-modernidade ${ }^{55}$. Hoje, como sempre, a questão da alteridade, tanto nas livrarias quanto alhures, continua sem uma solução adequada.

\section{Coda}

\section{Uma agenda para reflexão}

As novas representações híbridas geradas pelo encontro com a cultura/civilização européia dominante constituíram, no último século, espécies diversas de sínteses, mais ou menos radicais, a partir de duas vertentes: de um lado, as idéias e valores de inspiração autóctone e holista; de outro, as idéias e valores trazidos da configuração individualista moderna. Esses encontros geraram processos permanentes, duradouros, precisos. Deles resultou o fenômeno que faz com que quanto mais a civilização moderna se espal ha pelo mundo, mais a configuração individualista se modifica pela integração de produtos híbridos, tornando-a mais poderosa e, ao mesmo tempo, modificando-a pela permanente mistura de valores distintos 56 .

Fenômeno equivalente ocorre entre os cientistas sociais, que têm, no mínimo, uma inserção dupla e solidária: de um lado, como membros de uma comunidade transnacional que partilha ideologia, códigos, expectativas, rituais, e, não menos, autores clássicos - daí advindo seu caráter universal; de outro, como intelectuais políticos cuja socialização/identidade social se vincula a determinada nacionalidade: é indiano, brasileiro, australiano, inglês etc. - revelando, portanto, seu caráter particular. Em alguns casos, sobrepõe-se a essas uma identidade civilizacional (como é o caso asiático); em outros, hegemônica (a de "A merican", por exemplo). De Max Weber a N orbert Elias, o vínculo e a relativa autonomia visà-vis a idéia nacional foram questionados e avaliados ${ }^{57}$. Como outros fenômenos, essas são questões que devem ser focalizadas em uma perspectiva comparada. Concluo, portanto, explicitando al gumas dimensões que estiveram presentes nos casos examinados, de modo a servir como base para uma agenda de reflexão.

A comparação entre diversas vertentes da antropologia é um projeto sério e urgente. Presa, de um lado, de fáceis declarações de objetividade e universalismo, e, de outro, de noções subjetivas de conhecimento e relativismo excessivo, a comunicação entre os antropólogos precisa de uma convenção abrangente (na epígrafe de Vincent Crapanzano, "a fully governing convention") e, ao mesmo tempo, da força política que advém 
da aliança de múltiplos interesses e perpectivas - à qual Michael Fischer alude. Nesse contexto, vale relembrar como nos trabal hos examinados o reconhecimento de certos autores clássicos reafirmou-se paralelamente ao status privilegiado concedido à pesquisa de campo. Este processo indica que, na antropologia, a idéia de uma teoria como um Terceiro (peirceano) pode dispensar um corpo conceitual estável e definido, atribuindo essa função aos antecessores e, como conseqüência, à etnografia, e ambos, antecessores e etnografia, permitindo à história da antropologia transformar-se em uma multiplicidade de histórias teóricas. Assim, não importa se questionadas ou exaltadas, são as histórias teóricas que, finalmente, tornam possíveis as pretensões de um diálogo igualitário entre antropólogos de diferentes origens e orientações (todos temos as mesmas monografias em nossas bibliotecas; os casos de pesquisa de campo são partilhados socialmente; dados etnográficos são usados como metáforas produtivas).

M as é preciso ir além. Depois de focalizar diferenças, é imperativo ocupar o vértice oposto. Em primeiro lugar: é imprescindível reconhecer que, mesmo socialmente produzido, o saber acadêmico é relativamente autônomo em relação aos contextos imediatos de produção e pode, portanto, al cançar níveis desejáveis de comunicação. Em segundo lugar: a comparação, mais que o relativismo descontrolado, é a melhor garantia contra a homogeneização superficial, facilitando a comunicação intelectual responsável através de fronteiras nacionais e culturais. Por fim: é preciso interrogar as práticas atuais da antropologia nas interseções das histórias teóricas com as diversas abordagens por meio das quais a disciplina vem se estabelecendo socialmente, com as áreas de conhecimento vizinhas e com as tradições nacionais onde se implantam suas articulações teóricas mais amplas. Refletir sobre como essas questões podem se conjugar foi o objetivo deste exercício.

Recebido em 18 de junho de 1997

Aprovado em 15 de julho de 1997

Mariza G. S. Peirano é professora-titular do Departamento de A ntropologia da Universidade de Brasília. É autora de Uma Antropologia no Plural e A Favor da Etnografia. 


\section{Notas}

1 Ver Peirano (1995a:146-155) para a distinção entre histórias teóricas e historiografia.

2 A centralidade dos clássicos vem sendo reconhecida em várias áreas. $\mathrm{Na}$ sociologia, Alexander (1987; 1991) parte da constatação curiosa de que as ciências naturais não elegem clássicos. Para focalizar sua relevância nas ciências humanas, Alexander defende os clássicos com argumentos funcionais/externos (a necessidade de uma base mínima para comunicação e coerência) e intelectuais/internos (eles contribuem de maneira contínua e singular para a ciência da sociedade), sugerindo uma abordagem que denomina historical systematics. Calvino (1993) afirma a centralidade dos clássicos com argumentos mais ensaísticos e que remetem a uma dimensão mais abrangente. Ao distingui-los por meio da influência que exercem; ao indicar como eles se mimetizam como inconsciente coletivo ou individual; ao torná-los equivalentes ao universo, Calvino aponta para a dimensão cosmológica dos clássicos, abrindo espaço para apropriações individuais, em que o clássico eleito serve para definir, por relação ou contraste, o trabalho de cada autor.

3 Para a retomada da idéia de aculturação no contexto do mundo intelectual contemporâneo, ver Dumont (1994). Para a idéia de situated knowledges vis-à-vis as disciplinas, ver Haraway (1991:cap. 9); no Brasil, ver Santos (1995).

4 "A merican cultural anthropology today dominates the international scene, both in mass and quality, and is largely trend-setting for what we all try to do" (Barth 1996:1).

${ }^{5}$ Artigos de revistas especializadas questionam a disciplina, mas parte do nervosismo da área pode ser constatado na perspectiva oposta, como o recente debate "Objectivity and Militancy", publicado em Current Anthropology, com a participação de D'Andrade (1995) e Scheper-Hughes (1995). No mesmo contexto, Crapanzano (1991) denunciou o fundamentalismo de tipo "científico" e a American Anthropological Association conduziu, em 1996, o debate "Anthropology and Science", dele fazendo parte o excelente ensaio de Bruno Latour (1996).

${ }^{6}$ Estes últimos são designados pela sigla STS Programs.

7 Barth (1996) utiliza, com objetivo semelhante, as citações de artigos recentes. M inhas observações foram realizadas nos quatro últimos meses de 1995, período em que estive associada ao MIT, com bolsa de estágio senior do CNPq, e em novembro/dezembro de 1996.

8 Mais ainda, livrarias precisam ter seus estoques sempre disponíveis, o que hoje se traduz em horários ampliados e acesso eletrônico. O movimento da Har- 
vard Book Store, principal livraria que serve à comunidade de Harvard e M IT, pode ser avaliado pelo horário de atendimento: no mês de novembro, das 9:30 da manhã às 11 da noite, de segunda a quinta; nas sextas e sábados o horário estende-se até à meia-noite; domingos, de 10 da manhã às 10 da noite. Geralmente três pessoas nas caixas registradoras atendem a fila única; no mesmo balcão três outros funcionários recebem os pedidos de encomenda de livros (que normalmente são atendidos no período de uma a duas semanas). O acesso via internet facilita as aquisições, mas a maioria dos compradores prefere freqüentar a livraria.

9 Ver Eugen Weber (1976) para o exame histórico dessa proposta.

10 Ver W. Outhwaite e T. Bottomore (1993), aliás, já traduzido para o português. Para o anuário Late Editions, ver M arcus (1993a; 1995a). N a introdução à série, George M arcus define a antropologia como empírica e etnográfica, mas, implicada nas mesmas fontes teóricas e filosóficas que informam as Humanidades, ela encontra-se com os cultural studies: "Indeed, from the perspective of the institutional politics of disciplines, some would argue that the main dynamic in the development of cultural studies has been the attempt of literary studies to expand and transform itself into a more engaged, socially conscious activity" (M arcus 1993b:2). Propondo que os textos da série tenham como alvo privilegiado "[the] globally minded U.S. academics" (M arcus 1993b:3) e evoquem o trabal ho de jornalistas e correspondentes estrangeiros mais que as convenções disciplinares, M arcus define como um importante objetivo "to evoke a combined sense of familiarity and strangeness in U.S.-university educated readers by selecting subjects that share something of a frame of reference and experience with them, but then differ in often radical and startling ways from them by cultural background and situated fin-de-siècle predicament" (1993b:5).

$11 \mathrm{Na}$ estante de cultural and critical theory pode-se encontrar uma variedade de títulos que denotam a vanguarda de hoje (alguns exemplos: Postmodernism and Social Theory; The Postmodern Turn; Cyborg Handbook; The Post-Colonial Studies Reader; The Anthropology of Supermodernity; Colonial Desire), assim como a combinação eclética dos autores que inspiram essa vertente: M ichel Foucault está acompanhado por Paul Feyerabend, J acques Derrida, J ulia Kristeva, J ürgen Habermas, J ean Baudrillard, Edward Said, Walter Benjamin, Georg Lukács, Anthony Giddens, Herbert M arcuse, Louis Althusser, Theodor Adorno, Henri Lefebvre.

12 Ver Marcus (1995b) para as chamadas anti-disciplinary arenas.

13 Ver Sigaud (1995) para um exemplo da recepção de Scheper-Hughes aqui no Brasil. 
14 N ovamente a expressão é de George M arcus (1995b), e designa o tipo de etnografia em que os objetos de estudo são descontínuos quando focalizados da perspectiva de um sistema mundial.

15 Ver Peirano (1992a) para uma comparação entre as características da antropologia na Índia e no Brasil.

16 A qui basta citar as concepções da antropologia como "descrição", "colocar-se em perspectiva”, “comparação”, “interpretação” (ver Peirano 1981:cap.1).

17 As orientações pré-científica e pré-categórica são derivadas de Lacan (1981); a pré-psicológica é defendida por Crapanzano (1992); a pré-sociológica por Latour (1987).

${ }^{18}$ Cf. o subtítulo de Geertz (1995), Two Countries, Four Decades, One Anthropologist.

19 Ver Geertz (1983). M as em 1968 David Schneider já havia feito associação semelhante: "This is a society and culture that we know well. We speak the language fluently, we know the customs, and we have observed the natives in their daily lives. Indeed, we are the natives." (Schneider 1968:vi)

20 Ver Dumont (1986:cap. 8), onde o autor defende que a tensão entre o universalismo e a diferença nada ganha reduzindo-se a distância: "a difficult task and better entrusted to research workers who have gained experience elsewhere; this choice avoids the traumatic experience of dépaysement but contains the risk of remaining superficial" (:218).

21 Ver Srinivas (1952). Radcliffe-Brown destaca na introdução: “This book, by a trained anthropologist, who is himself an Indian, and who has therefore an understanding of Indian ways of thought which it is difficult for a European to attain even over many years, gives us a scientifically valuable and objective account of the religious behaviour of a particular Indian community" (RadcliffeBrown 1952:vii). A orientação da tese que originou o livro passou de RadcliffeBrown a seu substituto, Evans-Pritchard.

22 Ver Saberwal (1982; 1983). Para reflexões sobre pesquisa de campo “in one's own society", ver Béteille e Madan (1975); Srinivas (1979); Uberoi (1968).

23 Para o primeiro caso, ver J ackson (1987). Nos Estados Unidos, ver M arcus e Fischer (1986). Em ambos os casos, inglês e norte-americano, torna-se imperativo traçar uma genealogia que justifique tal empreendimento, quer de Raymond Firth e Max Gluckman, quer de M argaret M ead e Ruth Benedict. (M arcus e Fischer (1986) recupera M argaret M ead como inspiração; Geertz (1988) redime Ruth Benedict.) 
24 Para a denúncia do autor, ver Geertz (1988); do fato, Geertz (1995). O gênero narrativo valorizado contrapõe-se à validade dos fatos em um movimento mais amplo (ver Feyerabend 1995).

25 Nos programas de Science, Technology and Society, os antropólogos recém-chegados parecem ameaçar, com os novos gêneros, os historiadores mais tradicionais da área. Ver, por exemplo, Traweek (1988; 1992); Fischer (1994; 1995a; 1995b); Stone (1994a; 1994b; 1995); Rabinow (1996).

26 Ver Stone (1995) para os eventos ficcionais nos cultural studies norte-americanos.

27 Ver, especialmente, Madan (1982; 1987; 1989; 1992). Para uma resenha do livro de Geertz, ver Giumbelli (1996).

28 É nesse contexto de mudança relativa - os antropólogos sempre estiveram atentos à construção monográfica - que proliferam comentários do tipo "anthropology is no longer, if it ever was..." nos textos de antropólogos que partiIham a crença de uma ruptura: "Anthropology is no longer, if it ever was, the 'discovery' of terra nova or undescribed cultures or social structures" (Fischer 1995b:2); "A nthropology is no longer a singular discipline, if it ever was, but rather a multiplicity of practices engaged in a wide variety of social contexts" (Moore 1996:1).

29 Esse mesmo estilo tinha sido adotado em Geertz (1968).

30 Os temas incluem: uma discussão sobre a ideologia religiosa e a identidade étnica de hindus e muçulmanos em Caxemira, da época da partição da Índia até o início da violência mais recente; a mudança de identidade social no Bengal muçulmano antes e depois da fundação de Bangladesh; e a reação diferenciada da Índia e do J apão à influência do Ocidente. Ver Peirano (1995b) para uma resenha crítica de Pathways.

31 M as, em certo momento, Geertz aceita que "In the course of all this coming and going and knocking about surely there emerge some governing aims continuously worked toward, some practiced skills habitually exercised, some determinate standards repeatedly applied, some settled judgements as to what is knowable and what isn't, what will work and what won't, what matters and what doesn't." (Geertz 1995:134)

32 T. S. Eliot serve de epigrama para a segunda parte do livro: “A nd what there is to conquer / By strength and submission, has already been discovered / Once or twice, or several times, by men whom we cannot hope / To emulate... / For us, there is only the trying. The rest is not our business" (Madan 1994:109).

33 Essas imagens são combatidas na Índia pelos historiadores dos subaltern studies, que Madan indica, mas não nomina. Para Madan, contudo, o problema 
central não está nas diversas interpretações, mas na autoridade conferida pela literatura da ciência social ocidental a estudantes indianos a respeito de sua própria sociedade (Madan 1994:162-163). Sobre o “inimigo interno”, ver Nandy (1983).

$34 \mathrm{O}$ papel desempenhado por Madan precisa ser lido nas entrelinhas do capítulo 4 e nas notas de rodapé (cf., p. ex., Madan 1994:55, nota 1). Ver Peirano (1991; 1992a:cap. 9) para uma avaliação do impacto das discussões travadas na seção "For a Sociology of India", publicadas no segundo número de cada ano de Contributions to Indian Sociology.

35 O número de sócios da American Anthropological Association que, em 1950, era de 2 mil, passou a 10 mil em 1992.

36 O ponto de vista de que os ingleses deixaram a Inglaterra inquestionada é proposto por Anderson (1968) no contexto do desenvolvimento espetacular da antropologia inglesa vis-à-vis a sociologia.

37 M oore (1996) destaca a atração que a filosofia africana exerce para os cultural studies. Esse processo de incorporação seletiva pode ser iluminado pela idéia de aculturação intelectual, de Louis Dumont: "the confrontation of modern civilization with autochthonous cultures does not result simply in one-way borrowings. Quite to the contrary, the dominant partner borrows from the dominated not only isolated or special features like the outrigger canoe or African art, but also representations which in all good faith he believes to be his own while in actual fact they result from acculturation and therefore contain an unsuspected holistic component. [...] Indeed we can often verify that the new, hybrid representations are intensified as compared with the notions from which they proceed" (1994:15). Retorno a Dumont mais adiante.

38 Nesse sentido, o livro tem ênfase diversa do de Tambiah (1996). Tambiah distingue três maneiras de focalizar a violência coletiva: a antropologia dos aspectos coletivos da violência; a antropologia dos processos de migração; e a antropologia da dor. Nesse quadro geral, Das faz parte do terceiro tipo.

39 Ver, também, Das (1995b). Contrastar com o caso brasileiro, em que o outro é o oprimido, e não a vítima (Peirano 1981).

40 Os subaltern studies vêm sendo desenvolvidos por historiadores de origem indiana, sensíveis às questões da desigualdade, a partir da posição social dos "subalternos". A crítica a Dumont é ponto de partida para esses estudos (ver Guha e Spivak 1988). Ver Peirano (1992a) para os debates entre M. N. Srinivas e Louis Dumont nas décadas de 50 a 70 (capítulo 7) e entre Louis Dumont e A. K. Saran (capítulo 9).

${ }^{41}$ Considerar Dumont como o oponente privilegiado de Veena Das diferencia sua posição da de T. N. Madan, que o vê como outstanding pathfinder. No ras- 
tro da crítica de Das a Dumont, T. N. Madan sai chamuscado em nota em que a autora comenta a pesquisa de campo de indianos na Índia (Das 1995a:40). Ver, também, Das (1977).

42 Para Wittgenstein, a expressão "I am in pain" não é uma declaração que descreve um estado mental - é uma queixa; não é o fim do jogo de linguagem, mas seu início (apud Das 1995a:194-195). Veena Das recupera a discussão durkheimiana sobre os ritos piaculares de Les Formes Élémentaires de la Vie Religieuse.

43 Essa triangulação encontra paralelo em Peirano (1992a; 1992b).

${ }^{44}$ A revista Ethnos publicou em seu vol. 60, no 3-4, sob o título “Culture and Voice in Social Anthropology", as quatro conferências proferidas quando da homenagem a Veena Das.

45 Ver Rabinow (1992) para o tratamento que dispensou aos colegas brasileiros após visita ao país.

46 Em um único momento, uma linhagem intelectual é estabelecida, mas as referências não incluem nenhum antropólogo (a referência a Lévi-Strauss só surge no final do livro): "The social study of science (and technology) is today a burgeoning multidisciplinary field. Beginning with the work of Thomas Kuhn and Paul Feyerabend and accelerating with the studies of Bruno Latour, Karin KnorrCetina, Evelyn Fox Keller, Donna Haraway and many others, these diverse studies of the local practices of science have sought to bring the abstraction of Science, Reason, Truth, and Society down to earth." (Rabinow 1996:13)

47 O contraste de Making PCR com Latour (1984) é elucidativo.

48 N os agradecimentos de Rabinow, Traweek é a primeira da lista, mas seu livro não é citado. A autora, que também optou por uma construção monográfica clássica que focaliza aceleradores e físicos, rituais de iniciação, concepções de tempo e espaço, alguns anos mais tarde se disse desapontada porque os leitores não perceberam que ela havia feito um contraponto irônico a Evans-Pritchard: “Using an Englishman's ethnographies of Africans as the referent for the structure and tone of my ethnographies also offered some other useful ironies. [...] I wanted to invoke for my study of physicists E-P's insights about the significant cognitive relations between people and their animate/inanimate artifacts while exposing his and our colonialist assumptions" (Traweek 1992:436).

49 A introdução de Rabinow abre com a seguinte epígrafe, retirada de "A Ciência como Vocação": "Permit me to take you once more to America, because there one can often observe such matters in their most massive and original shape".

50 Se hoje Geertz (1995:16) é cético em relação ao "fateful incident", muitos consideram imprescindível estabelecer os "incidentes reveladores" que geram a 
etnografia (Fernandez 1990). Sally Falk M oore segue a trilha do "drama social" de Victor Turner para propor o reconhecimento de "momentos diagnósticos" e Luc Boltanski define "les grands moments". No Brasil, o recorte etnográfico de "casos" e "eventos rituais" (Bezerra 1995; Teixeira 1997) mostra o rendimento analítico desse tipo de abordagem; o foco em "reuniões" (Comerford 1996) permite delicadas análises, assim como as eleições presidenciais em pequenos municípios al cançam resultados abrangentes (Chaves 1993; 1996). Os exemplos são muitos: comícios (Palmeira 1994; Palmeira e Heredia 1995); possessão (Velho 1994); obtenção de documentos e debates acadêmicos (Peirano 1986; 1992a:cap.7). Em Elias (1996) o exemplo dos duelos é brilhante e, na literatura, Virginia Woolf cunhou o esplêndido moments of being (Woolf 1985).

51 Nesse sentido, contrastar, por exemplo, os lugares de fala de Pandey (1995) e Stocking J r. (1982).

52 Fica também indicado o vínculo entre a idéia de "causação adequada" de Weber e a percepção dos eventos, tal como focalizada da perspectiva de uma “antropologia simétrica”, por Latour (1995). O contexto é o encontro de Louis Pasteur e o ácido lático, ambos "eventos" recíprocos.

53 Não sabemos se os livros são difíceis de encontrar por estarem esgotados ou por serem mal distribuídos pela Oxford University Press da Índia.

$54 \mathrm{Na}$ Índia, antropólogos estão freqüentemente vinculados a departamentos de sociologia, mas as razões históricas e sociais para essa associação são de ordem diversa (ver Peirano 1992a:cap.7). O livro de Antonio Candido, On Literature and Society, também foi classificado como sociologia nos Estados Unidos. M as, confirmando as hipóteses anteriores, Viveiros de Castro (1992) encontra-se na estante de antropologia.

55 Esse fenômeno foi descrito como "a infinite regress of heterogeneity" em A hmad (1995:26-27). A hmad trata especificamente do termo postcolonialism: "It is only when the Angel of History casts its glance back at Asian and African societies from its location in Europe and North America, or when it flies across the skies of the world on the wings of postmodern travel and telecommunication, that those societies look like so many variants of a postcolonial sameness" (:28). No caso dos cultural studies, estes incorporam os trabalhos de Gayatri Spivak, Gyan Prakash, Homi Bhabha, Ashis Nandy, Aijaz A hmad, os interlocutores europeus ou norte-americanos (como Edward Said e Frederic J ameson), além dos múltiplos clássicos dessa vertente (cf. nota 11).

56 Essas idéias estão elaboradas, para os casos alemão e francês em particular, em Dumont (1994).

57 Cf. Weber (1946), especialmente a parte sobre "Structures of Power"; Elias (1971) para a relativa autonomia; Elias (1978) para a idéia nacional. 


\section{Referências bibliográficas}

ABU-LUGHOD, Lila.1993. Writing Women's Worlds. Bedouin Stories. Berkeley: University of California Press.

AHM AD, Aijaz.1995. "Postcolonialism: What's in a Name?". In: R. de la Campa, E. Kaplan e M. Sprinker (eds.), Late Imperial Culture. London: Verso. pp. 11-32.

ALEXANDER, J effrey.1987. "The Centrality of the Classics". In: A. Giddens e J. H. Turner (eds.), Social Theory Today. Stanford: Stanford University Press. pp. 11-57.

.1991. "Sociological Theory and the Claim to Reason: Why the End Is N ot in Sight". Sociological Theory, 9(2):147-153.

ANDERSON, Perry. 1968. “The Components of a National Culture". New Left Review, 50:3-57.

BARTH, Fredrik.1996. The Practise of American Cultural Anthropology: A View from the Margins. Trabalho apresentado no painel How Others See Us: American Cultural Anthropology as the Observed rather than the Observer. AAA Meeting, San Francisco.

BÉTEILLE, A. e MADAN, T. N. (eds.). 1975. Encounter and Experience: Personal Accounts of Fieldwork. Honolulu: Hawaii University Press.

BEZERRA, Marcos Otávio. 1995. Corrupção. Um Estudo sobre Poder Público e Relações Pessoais no Brasil. Rio de J aneiro: Relume-Dumará.

CALVINO, Ítalo. 1993. Por que Ler os Clássicos. São Paulo: Companhia das Letras.

CANDIDO, Antonio. 1995. On Literature and Society (traduzido, editado e introduzido por Howard Becker).
Princeton: Princeton University Press.

CHAVES, Christine Alencar. 1993. Buritis: Festas, Política e M odernidade no Sertão. Dissertação de M estrado, Departamento de Antropologia/ UnB.

. 1996. “A Pessoa Política: Eleições em Buritis, Minas Gerais". In: $M$. Palmeira e M. Goldman (eds.), Voto, Representação e Eleições. Rio de J aneiro: Contra Capa. pp. 127-164.

COMERFORD, John. 1996. Reunir e Unir: As Reuniões de Trabalhadores como Forma de Sociabilidade. Dissertação de M estrado, PPGAS/M useu Nacional/UFRJ .

CRAPANZANO, Vincent. 1991. "The Postmodern Crisis: Discourse, Parody, Memory". Cultural Anthropology, 6(4):431-446.

. 1992. Hermes' Dilemma \& Hamlet's Desire. On the Epistemology of Interpretation. Cambridge, M ass.: Harvard University Press.

D'ANDRADE, Roy. 1995. “Moral Models in Anthropology". Current Anthropology, 36(3):399-408.

DAS, Veena. 1977. Structure and Cognition: Aspects of Hindu Caste and Ritual. Delhi: Oxford University Press. . 1995a. Critical Events. An Anthropological Perspective on Contemporary India. Delhi: Oxford University Press.

. 1995b. "Voice as Birth of Culture". Ethnos, 60(3-4):159-179.

DUM ONT, Louis. 1986. Essays on Individualism. Modern Ideology in Anthropological Perspective. Chicago: The University of Chicago Press. 1994. German Ideology. From France to Germany and Back. Chicago: The University of Chicago Press. 
ELIAS, Norbert. 1971. "Sociology of Knowledge: New Perspectives". Sociology, 5:49-168 (Parte 1); 355-370 (Parte 2).

. 1978. The Civilizing Process. New York: Urizen Books.

. 1996. The Germans. Power Struggles and the Development of Habitus in the Nineteenth and Twentieth Centuries. New York: Columbia University Press.

FEI, Hsiao-Tung. 1939. Peasant Life in China: A Field Study of Country Life in the Yangtze Valley (prefácio de Bronislaw Malinowski). New York: E. P. Dutton.

FERNANDEZ, J ames. 1990. “Tolerance in a Repugnant World". Ethos, 18(2):140-164.

FEYeRABend, Paul. 1995. Killing Time. Cambridge, M ass.: Harvard University Press.

FIRTH, Raymond e DJ AM OUR, J . 1956.

Two Studies of Kinship in London. London: Athlone Press.

FISCHER, Michael M. J . 1994. “Autobiographical Voices $(1,2,3)$ and Mosaic Memory: Experimental Sondages in the (Post)M odern World". In: K. Ashley, L. Gilmore e G. Peters (eds.), Autobiography and Postmodernism. Amherst: University of Massachusetts. pp. 79-127. .1995a. "Eye(I)ing the Sciences and their Signifiers (Language, Tropes, A utobiographers): Interviewing for a Cultural Studies of Science and Technology". In: G. Marcus (ed.), Technoscientific Imaginaries. Conversations, Profiles, and Memoirs (Late Editions 2). Chicago: The University of Chicago Press. pp. 43-84. . 1995b. Otobiotopographies: Anthropology in New Worlds of Science \& Technology. Trabalho apresentado na Universidade de M ontreal, outubro. e ABEDI, M. 1990. Debating Muslims: Cultural Dialogues in Postmodernity and Tradition. Wisconsin: University of Wisconsin Press.

GEERTZ, Clifford. 1968. Islam Observed. Religious Development in Morocco and Indonesia. Chicago: The University of Chicago Press.

. 1983. Local Knowledge. Further Essays in Interpretative Anthropology. New York: Basic Books.

. 1988. Works and Lives. The Anthropologist as Author. Stanford: Stanford University Press.

. 1995. After the Fact. Two Countries, Four Decades, One Anthropologist. Cambridge, Mass.: Harvard University Press.

GIUMBELLI, Emerson. 1996. Resenha de After the Fact, de Clifford Geertz. Mana, 2(1):183-187.

GUHA, Ranajit e SPIVAK, Gayatri Chakravorty. 1988. Selected Subaltern Studies. Oxford: Oxford University Press.

HARAWAY, Donna J . 1991. Simians, Cyborgs, and Women. The Reinvention of Nature. New York: Routledge.

JACKSON, Anthony. 1987. "Reflections on Ethnography at Home and the ASA". In: A. Jackson (ed.), Anthropology at Home. London: Tavistock Publications. pp. 1-15.

LACAN, J acques. 1981. The Fundamental Four Concepts of Psycho-A nalysis. New York: W.W. Norton \& Company.

LATOUR, Bruno. 1984. The Pasteurization of France. Cambridge, Mass.: Harvard University Press. . 1987. Science in Action. Cambridge, Mass.: Harvard University Press.

1995. Do Scientific Objects Have a History Too? An Encounter between Pasteur and Whitehead in a 
Lactic A cid Bath. Manuscrito. (Traduzido de "Les Objets Ont-ils une Histoire? Rencontre de Pasteur et de Whitehead dans un Bain d'Acide Lactique". In: I. Stengers (ed.), L'Effet Whitehead. Paris: Vrin, 1994. pp. 197-217.)

. 1996. "N ot the Question". Anthropology Newsletter, 37(3):1.

MADAN, T. N. 1987. Non-Renunciation. Themes and Interpretations of Hindu Culture. Delhi: Oxford University Press.

. 1989 [1965]. Family and Kinship.

A Study of the Pandits of Rural Kashmir (2 ${ }^{a}$ ed. ampliada). Delhi: Oxford University Press.

.1994. Pathways. Approaches to the Study of Society in India. Delhi: Oxford University Press.

(ed.). 1982. Way of Life. King, Householder, Renouncer. Essays in Honour of Louis Dumont. New Delhi: Vikas Publishing House.

. 1992. Religion in India. Delhi: Oxford University Press.

MALINOWSKI, Bronislaw. 1939. "Preface". In: H.-T. FEI, Peasant Life in China: A Field Study of Country Life in the Yangtze Valley. New York: E.

P. Dutton. pp. xix-xxvi.

MARCUS, George. 1993b. "Introduction to the Series and to Volume 1". In: G. Marcus (ed.), Perilous States. Conversations on Culture, Politics, and Nation (Late Editions 1). Chicago: The University of Chicago Press. pp. 1-16.

.1995b. "Ethnography in/of the World System: The Emergence of Multi-Sited Ethnography". Annual Review of Anthropology, 24:95-117. (ed.). 1993a. Perilous States. Conversations on Culture, Politics, and Nation (Late Editions 1). Chicago: The University of Chicago Press. . 1995a. Technoscientific Imaginar- ies. Conversations, Profiles, and Memoirs (Late Editions 2). Chicago: The University of Chicago Press.

MARCUS, George e FISCHER, Michael M. J . 1986. Anthropology as Cultural Critique. An Experimental Moment in the Human Sciences. Chicago: The University of Chicago Press.

MAUSS, Marcel. 1925. “Essai sur le Don. Forme et Raison de l'Échange dans les Sociétés Archaïques". L'Année Sociologique (n.s.), 1:30-186.

MOORE, Henrietta. 1996. “The Changing Nature of Anthropological Knowledge". In: H. Moore (ed.), The Future of Anthropological Knowledge. New York: Routledge. pp. 1-15.

NANDY, Ashis. 1983. The Intimate Enemy. Loss and Recovery of Self under Colonialism. Delhi: Oxford University Press.

OUTHWAITE, W. E BOTTOM ORE, T. 1993. Twentieth-Century Social Thought. London: Blackwell.

PALMEIRA, M oacir G. S. 1994. Antropologia e Política. Conferência realizada como requisito para concurso de professor-titular. PPGAS/MN/UFRJ, Rio de J aneiro, 25 de outubro. e HEREDIA, Beatriz. 1995. "Os Comícios e a Política de Facções”. Anuário Antropológico 94:31-94.

PANDEY, Gyanendra. 1995. “Voices from the Edge: The Struggle to Write Subaltern Histories". Ethnos, 60(3-4): 223-242.

PEIRANO, Mariza G. S. 1981. The Anthropology of Anthropology: The Brazilian Case. Ph.D. Dissertation, Harvard University. . 1986. "Sem Lenço, Sem Documento: Reflexões sobre Cidadania no Brasil". Sociedade e Estado, 1(1): 49-64.

. 1991. "For a Sociology of India: Some Comments from Brazil". Con- 
tributions to Indian Sociology (n.s.), 25(2):321-328.

. 1992a. Uma Antropologia no Plural. Três Experiências Contemporâneas. Brasília: Editora da Universidade de Brasília.

. 1992b. Não Foi Só por Acaso: Um Depoimento. Memorial para concurso de professor-titular. UnB, Brasília, 23 de setembro.

. 1995a. A Favor da Etnografia. Rio de J aneiro: Editora Relume-Dumará.

1995b. "Trilhas Indianas da Antropologia". Anuário Antropológico/ 94:293-300.

RABINOW, Paul. 1992. “A Modern Tour in Brazil". In: S. Lash e J . Friedman (eds.), Modernity and Identity. London: Blackwell. pp. 248-264.

.1996. Making PCR. A Story of Biotechnology. Chicago: The University of Chicago Press.

RADCLIFFE-BROWN, A. R. 1952. “Introduction". In: M. N. Srinivas, Religion and Society among the Coorgs of South India. Oxford: Clarendon Press. pp. vii-xi.

SABERWAL, Satish. 1982. "For a Sociology of India: On Multiple Codes". Contributions to Indian Sociology, 16(2):289-294.

.1983. "Uncertain Transplants: Anthropology and Sociology in India". Contributions to Indian Sociology, 17(2):301-315 (Reproduzido de Ethnos, 47:36-49).

SANTOS, Maria Cecília Mac Dowel. 1995. “Quem Pode Falar, Onde e Como? Uma Conversa ‘Não-Inocente' com Donna Haraway". Cadernos Pagu, 5:43-72.

SCHEPER-HUGHES, Nancy. 1992. Death without Weeping. The Violence of Everyday Life in Brazil. Berkeley, Los Angeles and Oxford: University of California Press.
. 1995. "The Primacy of the Ethical. Propositions for a M ilitant Anthropology". Current Anthropology, 36(3):409-420.

SCHNEIDER, David. 1968. American Kinship. A Cultural Account. Englewood Cliffs, N.J .: Prentice-Hall.

SIGAUD, Lygia. 1995. “'Fome' e Comportamentos Sociais: Problemas de Explicação em Antropologia". Mana, 1(1):167-175.

SRINIVAS, M. N. 1952. Religion and Society among the Coorgs of South India. Oxford: Clarendon Press. (ed.). 1979. The Fieldworker and the Field. Oxford: Oxford University Press.

STOCKING J R., George. 1982. "Afterword: A View from the Center". Ethnos, 47:172-186.

STONE, Allucquère Rosanne. 1994a. "Innocence and Awakening: Cyberdämmerung at the Ashibe Research Lab". In: G. M arcus (ed.), Science, Technology, and Culture (Late Editions 2). Chicago: The University of Chicago Press. pp. 177-195.

. 1994b. "What Vampires Know: Transsubjection and Transgender in Cyberspace". In: E. Ursprung (ed.), In Control: Mensch-I nterface-M achine. Graz: Kunstverein W.A.S. . 1995. The War of Desire and Technology at the Close of the Mechanical Age. Cambridge, Mass.: MIT Press.

TAMBIAH, Stanley J. 1996. Leveling Crowds. Ethnonationalist Conflicts and Collective Violence in South A sia. Berkeley: University of California Press.

TEIXEIRA, Carla Costa.1997. A Honra da Política. "Decoro Parlamentar" e Perda de Mandato no Congresso Brasileiro (1949-1994). Tese de Doutorado, Departamento de Antropologia/UnB. 
TRAWEEK, Sharon. 1988. Beamtimes and Lifetimes. The World of High Energy Physicists. Cambridge, M ass.: Harvard University Press. . 1992. “Border Crossings: Narrative Strategies in Science Studies and among Physicists in Tsukuba Science City, J apan". In: A. Pickering (ed.), Science as Practice and Culture. Chicago: The University of Chicago Press. pp. 429-465.

UBEROI, J. P. S. 1968. "Science and Swaraj". Contributions to Indian Sociology (n.s.), 2:119-128.

VELHO, Gilberto. 1994. “Unidade e Fragmentação em Sociedades Complexas". In: Projeto e M etamorfose. Antropologia das Sociedades Complexas. Rio de J aneiro: J orge Zahar Editor. pp. 11-30.

VIVEIROS DE CASTRO, Eduardo. 1992. From the Enemy's Point of View. Humanity and Divinity in an Amazonian Society. Chicago: The University of Chicago Press.

WEBER, Eugen. 1976. From Peasants into Frenchmen. The Modernization of Rural France. Stanford: Stanford University Press.

WEBER, Max. 1946. From Max Weber (traduzido, editado e com uma introdução de H. H. Gerth e C. Wright Mills). Oxford: Oxford University Press.

. 1992 [1906]. “Estudos Críticos sobre a Lógica das Ciências da Cultura". In: Metodologia das Ciências Sociais (tradução de Augustin Wernet). São Paulo/Campinas, SP: Cortez/Editora da Unicamp.

WOOLF, Virginia. 1985. M oments of Being (editado, com uma introdução e notas, por J eanne Schlkind). New York: Harcourt \& Brace Company. 
Resumo

Este artigo examina o cenário da antropologia contemporânea mediante o contraste entre quatro livros publicados nos últimos anos, dois nos Estados Unidos (After the Fact, de Clifford Geertz, e M aking PCR, de Paul Rabinow) e dois na Índia (Pathways, de $T$. N. Madan, e Critical Events, de Veena Das). A comparação é realizada no contexto de uma breve etnografia das livrarias norte-americanas, na qual se avaliam algumas publicações recentes, assim como a reclassificação de disciplinas tradicionais. O papel indispensável dos autores e obras considerados clássicos é examinado no contexto atual, finalizando com uma agenda para reflexão sobre as possibilidades de comunicação entre antropólogos de várias origens e vertentes.

\section{Abstract}

This article examines the setting of contemporary anthropology by means of the contrast between four books recently published in the United States (After the Fact by Clifford Geertz and Making PCR by Paul Rabinow) and India (Pathways by T. N. Madan and Critical Events by Veena Das). The comparison is made in the context of a brief ethnographic study of bookstores in the United States which evaluates several recent publications, as well as the reclassification of traditional disciplines. The indispensable role of the authors in works considered classics is examined in presentday context, concluding with a reflection on the possibility of communication between anthropologists of diverse backgrounds and perspectives. 